Nuntius Antiquus, Belo Horizonte, v. 13, n. 2, p. 7-15, 2017

\title{
Entre aporias, dilemas, paradoxos e labirintos - uma explicação sobre escolhas, à guisa de introdução
}

\section{Among Aporias, Dilemmas, Paradoxes, and Labyrinths - an Explanation about Choices by way of Introduction}

\author{
Maria Cecília de Miranda Nogueira Coelho \\ Departamento de Filosofia \\ Universidade Federal de Minas Gerais, Belo Horizonte, Minas Gerais / Brasil \\ ceciliamiranda@ufmg.br
}

Éramos, antes, absolutamente ridículos. Como as crianças a perseguir calhandras, acreditávamos, o tempo todo, agarrar, de repente, cada uma das ciências, mas elas sempre escapavam. Assim sendo, por que te contaria por extenso? Chegando porém à arte real, e examinando-a cabalmente se esta seria a que traz e realiza a felicidade, aí, como que caindo num labirinto, quando acreditávamos já estar no fim, ficou evidente que, tendo retornado sobre nossos passos, estávamos, de novo, como que no início da pesquisa, e carentes igualmente de quanto $<$ carecíamos $>$ quando pesquisávamos no começo. ${ }^{1}$

(Platão, Eutidemo, 291b-c, tradução de Maura Iglesias)

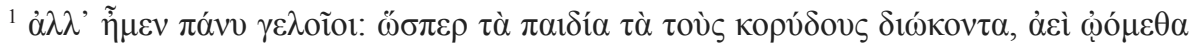

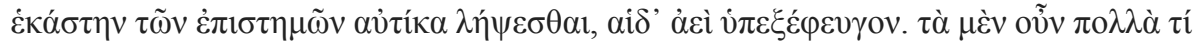

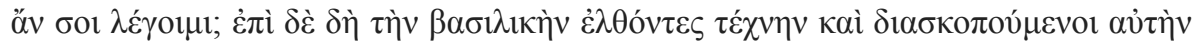

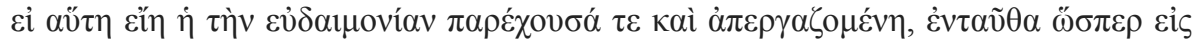

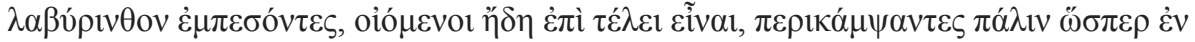

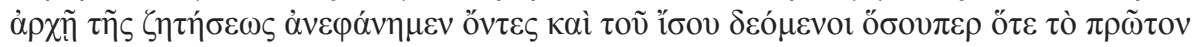
$\dot{\varepsilon} \zeta \eta \tau o \tilde{u} \mu \varepsilon v$. (Fonte: www.perseus.tufts.edu)
}

eISSN: $1983-3636$

DOI: $10.17851 / 1983-3636.13 \cdot 2.7-15$ 
Novamente, como editora convidada, tenho a satisfação de organizar um número especial para a revista Nuntius Antiquus. Assim como o volume 2 , de 2016, no qual foram reunidos artigos derivados das palestras apresentadas no "VI Simpósio Lendo, Vendo e Ouvindo o Passado - Eros e Helena, de Tróia a Vila Rica", ${ }^{2}$ este volume 2, de 2017, que ora edito, também é decorrente do mesmo simpósio, cujo tema, nesta sua VII edição, foi contemplado pelo seguinte subtítulo: "Entre Aporias, Dilemas, Paradoxos e Labirintos". Dos vinte e dois palestrantes convidados, ${ }^{3}$ quatorze puderam submeter artigos para publicação, formando um conjunto que, se não é completo (em relação ao apresentado no simpósio), é bastante representativo da variedade e da complexidade de temas e metodologias abordados com estes quatro conceitos-chave

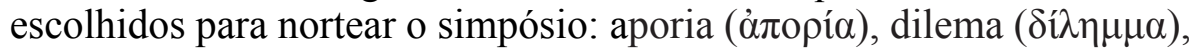

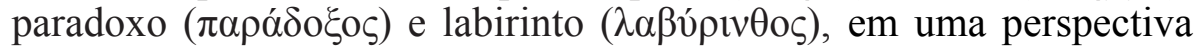
diacrônica. Como escrevi na apresentação do referido simpósio, no website a ele destinado, além da proximidade semântica, todos esses termos são encontrados em textos da Antiguidade, perpassando a cultura ocidental e adquirindo significados ora mais específicos, ora mais gerais, ora literais, ora metafóricos. Todos eles denotam conceitos variados e são traduzidos por palavras diversas, e a investigação de seus sentidos é objetivo de cada um dos artigos aqui publicados.

A palavra "labirinto" talvez seja, das quatro selecionadas, a mais comum; porém, os conceitos ligados a ela não são os mais simples seria até um oximoro. Basta folhear o monumental livro de Hermann $\mathrm{Kern}^{4}$ para observar a complexidade do símbolo e do conceito, cujas representações visuais ocorriam já no período pré-histórico, em geral

\footnotetext{
${ }^{2} \mathrm{Cf}$. http://www.periodicos.letras.ufmg.br/index.php/nuntius_antiquus/issue/view/535. Até aquele momento a reforma ortográfica não estava em vigor e a palavra "Troia" possuía acento.

${ }^{3}$ A programação completa, com os títulos das palestras, bem como com outras informações sobre o simpósio, no qual aconteceu também uma mostra de filmes sobre o tema, pode ser consultada por meio deste site: www.letras.ufmg.br/labirintos.

${ }^{4}$ KERN, H. Through the Labyrinth: Designs and Meanings Over 5.000 Years. Munich; London: Prestel, 2000. A edição em inglês é uma tradução da edição alemã, de 1983, que, por sua vez, é uma ampliação do extenso catálogo, em italiano (publicado pela Feltrinelli, em 1981), de uma exposição sobre o mesmo tema realizada naquele ano, sob a curadoria de Kern, paralelamente ao congresso Il Labirinto, que teve Jorge Luis Borges como presidente de honra.
} 
dissociadas de uma narrativa mitológica, mas algumas vezes conectadas com a lenda cretense, quando moedas mostram diagramas combinados com a cabeça de um touro (Kern, cap. 1). Habitualmente, os estudiosos do tema referem-se ao mitológico labirinto baseando-se em Homero (Il., 18, 590-2): o espaço para Ariadne, a filha de Minos, dançar, desenhado no escudo de Aquiles. No entanto, são de Plínio, Ovídio e Virgílio os relatos mais influentes na transmissão da imagem do labirinto, ${ }^{5}$ bem como das histórias sobre Pasífae, Minos, o Minotauro, Dédalo, Ícaro, Teseu, Ariadne e Fedra.

Por outro lado, chama atenção como o mito "escorre a entrar na realidade" (lembrando o verso de Pessoa), quando, no início do Fédon (58a-c), Platão relata a situação de Sócrates, já condenado à morte, mas esperando (qual o Astérion de Jorge Luis Borges) seu "sacrificador", sua liberdade, pois ele só poderá ser executado quando retornar o navio que anualmente repetia, como percurso ritual, a viagem de Teseu a Creta, relembrando a execução do Minotauro, preso no famoso artefato construído por Dédalo. Importantes também, mas de outra natureza, são os relatos - como os de Heródoto ou Plínio - de labirintos no Egito ou na Etrúria, ou as questões advindas do fato de que é da Renascença, mais especificamente do ano de 1420, o registro da mais antiga descrição pictórica de um labirinto com várias saídas e vários caminhos cegos. Até então, como observou Kern (2001, p. 23), a descrição gráfica de um labirinto era sempre a de um espaço no qual havia apenas um caminho a ser seguido, sendo impossível a desorientação, o que contraria as narrativas literárias mais antigas, que o descrevem com várias saídas e vários pontos cegos, imaginário em relação ao passado que se sobrepôs aos dados da cultura material.

Se os significados e a iconografia relativos ao conceito de labirinto vêm sendo, na arquitetura e na literatura, tão profícuos e variados ao longo dos séculos, e presentes em tantos campos também, os outros três termos - "dilema", "aporia" e "paradoxo" - e conceitos a eles ligados, quiçá por não estarem conectados a relatos mitológicos e a representações visuais, não têm a mesma fama e o mesmo tratamento. Embora sua utilização não esteja restrita ao vocabulário especializado, é principalmente no ambiente acadêmico que vamos lidar com os conceitos

${ }^{5}$ Veja DOOB, P. R. The Idea of the Labyrinth: from Classical Antiquity through the Middle Ages. Ithaca: Cornell University Press, 1992, especialmente o capítulo 1. 
ligados a tais termos. $\mathrm{Na}$ filosofia e em áreas afins, expressões como "diálogos aporéticos de Platão", "paradoxos lógicos" ou "dilemas morais" são constantes, enquanto "labirinto" serve, em geral, como imagem metafórica reveladora e poderosa dos meandros da reflexão filosófica ou da condição humana (como na epígrafe acima). Dilema, literalmente uma premissa dupla, talvez seja o mais novo termo técnico, aparecendo em gramáticos e lógicos do século II (período helenístico). Objeto de profundas investigações na ética e na filosofia política, dilemas morais - situações em que o agente moral tem de escolher fazer uma dentre duas ações em conflito - não deixam de ser, também, um material fértil para a literatura e para a dramaturgia, produzindo, por sua vez, por meio de ações de personagens ficcionais, modelos comportamentais que têm impacto na maneira de atuar de pessoas na vida cotidiana.

Quanto a "paradoxo" e "aporia", frequentemente, a análise dos termos na literatura acadêmica nos conduz aos filósofos gregos. Para mencionar exemplos paradigmáticos, recordemos dois casos. Primeiro, as famosas três ondas, ou teses paradoxais - frontalmente contrárias à opinião comum -, apresentadas na República (472a): (1) a igualdade entre homens e mulheres, (2) a comunidade de mulheres e (3) a maior

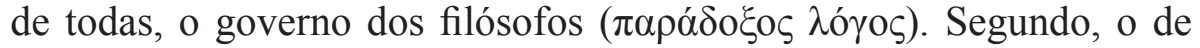
que, assim como Prometeu - "premido pelo impasse ( $\dot{\alpha} \pi$ opí $\alpha)$ " de qual salvação encontraria para o homem, rouba o fogo dos deuses, conforme lemos no Protágoras (321c) -, Platão traz a dialética como método para nos conduzir, como o fio de Ariadne, à atividade reflexiva. Inegável não ver o impacto que os termos tiveram na posteridade, após o tratamento deles por Platão.

Herdeiros desse vocabulário, também via Aristóteles, e outros pensadores que forjaram os termos, as imagens e os conceitos com os quais ainda lidamos, aqui nos vemos, (re)lendo o passado, estimulados pelos artigos dos palestrantes, aos quais é oportuno agradecer, penhoradamente, por terem, em um período de tempo tão reduzido - apenas sete meses desde a realização do simpósio até a entrega dos artigos -, explorado essas palavras e os conceitos correlatos segundo suas respectivas áreas de estudo, e revisto seus textos, preparados para uma comunicação oral, reelaborando-os, em seu conteúdo e formato, e submetendo-os à revista Nuntius Antiquus (e a seus pareceristas). Muito obrigada, autores.

Antes de deixar o leitor na companhia dos quatorze artigos, passo, brevemente, a indicar algumas decisões nas suas escolhas e nos seus 
arranjos, sem sintetizar o que cada artigo discute, pois essa é a função dos resumos feitos pelos próprios autores, não sendo, assim, necessário repeti-los nesta introdução.

Os dois primeiros artigos deste volume foram escritos pelos classicistas Frederick Ahl e Ioannis Petropoulos, e intitulados, respectivamente, "Moving Labyrinths: Virgil's Art of Multiple Narrative" e "Religious Paradox and Aporia". Embora o texto de Frederick se detenha em Virgílio, ele apresenta um quadro geral da origem do termo "labirinto", lembrando o papel que - além de Virgílio - Heródoto, Plínio, Ovídio Ps.-Apolodoro e outros historiadores e geógrafos tiveram para o nosso conhecimento do termo e de sua história, bem como dos locais onde foram encontrados, como construções, e dos seus habilidosos arquitetos. Escolher o autor da Eneida como foco, foi, nesse sentido, muito pertinente, pois seu texto ficcional tem grande interface com elementos históricos, e sua escrita não apenas nos revela um conteúdo específico sobre o tema, mas - há que se destacar, como o faz Ahl! é ela mesma, em sua forma, uma construção labiríntica, que atrai e prende o leitor. Quanto ao texto de Ioannis, ele nos traz uma estimulante análise comparativa dos termos/conceitos de aporia e paradoxo, com base em obras da literatura e da filosofia pagã e cristã, abarcando as perspectivas filosóficas e literárias. Além de explorar cuidadosamente todo o vocabulário correlato aos dois termos estudados, o autor elenca e analisa um número muito grande e variado de importantes escritores da filosofia e da literatura, mostrando criteriosamente a recepção dos conceitos gregos no Cristianismo.

Em seguida, temos três artigos dedicados a aspectos de obras de Platão, escritos por três filósofos, quais sejam: "Dilemas na tradução da República", de Rodolfo Lopes, "Drama e aporia no Mênon", de Richard Romeiro, e "A querela entre filosofia e poesia no Protágoras: uma aporia", de Luiz Paulo Rouanet. Enquanto o primeiro usa o termo "dilema" para tratar de suas decisões metodológicas e conceituais na sua longa (e bem-vinda!) empreitada de tradução da República, os dois últimos se concentram em questões específicas de dois diálogos. O destaque dado a Platão no simpósio teve duas razões: a primeira, por sua importância indiscutível no tratamento de alguns dos termos em discussão no simpósio, em particular os de paradoxo e aporia (como busquei indicar acima); a segunda, porque neste simpósio foi dedicado um momento especial para homenagear o saudoso platonista Marcelo 
Pimenta Marques, querido colega que foi também um dos apoiadores na organização desses encontros nos últimos oito anos. Se não temos, aqui, os textos de todos os integrantes da mesa dedicada aos dois, que, além de Richard Romeiro, contou com Diogo Mesti e Venúncia Coelho, outros dois ex-orientandos de Marcelo, que já haviam se comprometido com outras publicações, os textos de Lopes e Rouanet se agregam na homenagem e indicam o peso do filósofo grego na discussão de tais conceitos.

Com os três textos seguintes, "Paradoxes cyniques: l'activité littéraire d'Antisthène et de Diogène de Sinope", de Olimar FloresJúnior, "Teseu entre as disforias da glória e euforias do eu - as marcas da mudança na poesia romana", de Wellington Ferreira Lima, e "O dilema das relações internacionais sob a ascensão de Roma no Mediterrâneo, 350-200 a.C.", de Rafael Scopacasa, continuamos no mundo antigo, mas em outra perspectiva, se compararmos com o conjunto anterior - e trazer Antístenes e Diógenes de Sínope logo após Platão realça certo contraste. Em seu texto, o helenista Olimar (que, aliás, moderou a mesa sobre Platão) parte de uma passagem pontual de Diógenes Laércio (VI, 103-4) e analisa detalhadamente o problema do (aparente) paradoxo entre reflexão téorica e prática de um modo de vida filosófico, principalmente de Diógenes. Ademais, ele expande sua análise (que inclui uma perspicaz

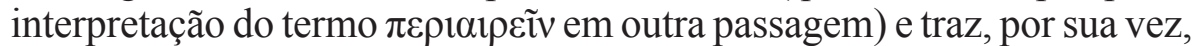
elementos para reconsiderar a questão complexa na história da filosofia antiga da (re)construção do cinismo, segundo uma perspectiva dos estóicos, indo de Sócrates a Zenão, passando por Antístenes e Diógenes, e concluindo que, paradoxalmente, ao mesmo tempo que a ambos possa ser atribuída uma radicalização da famosa crítica do Sócrates à escrita no Fedro, não há uma negação da cultura ou da escritura e da leitura. Os dois artigos seguintes abordam a literatura e a história romanas. Lima o faz por meio da análise do tema do labirinto, mais precisamente do mito de Teseu, no Carmen 64 de Catulo, famoso epílio no qual, embora o herói grego quantitativamente ocupe maior espaço, é de Ariadne o protagonismo. Destaca-se que, na medida em que a importância do papel feminino (e do sofrimento, consequência da situação aporética em que ela é deixada, reforçada pela imagem da ilha) ganha destaque, não deixa de ser paradoxal, ao mesmo tempo, a busca de uma justificação (no caso a interferência e o desejo de Dioniso) para o comportamento (aparentemente) desdenhoso de Teseu. Por fim, o artigo de Scopacasa 
nos transporta dos dramas e dilemas ficcionais para aqueles reais, no contexto da ascensão de Roma e seu impacto na articulação entre os Estados italianos. Com base nos relatos historiográficos de Políbio e de Tito Lívio, ele analisa a expansão de Roma no Mediterrâneo, em um exercício meticuloso - considerando serem essas obras tardias em relação ao período narrado e romanocêntricas -, para mostrar como, paradoxalmente, a segurança se mantinha em um contexto internacional anárquico e violento, em meio a posturas agressivas desses Estados e de Roma mesmo, e conclui, ciceronianamente, relembrando o valor pedagógico que o estudo da história do mundo antigo pode ter para os dilemas modernos no jogo das relações internacionais.

Com os artigos de Maurizio Filippo Di Silva, "Aporias nas relações entre tempo e movimento nas Confissões (XI-XII)", de Nastassja Pugliese, "Os paradoxos do início da metafísica moderna", e de Giorgia Cecchinato, "Il labirinto e l'artista. La esfinge e la statua nelle Lezioni di estética di G. W. F. Hegel", temos, novamente, três filósofos explorando cuidadosamente a recepção de alguns termos-chave em obras filosóficas de autores bem diferentes e bastante afastados temporalmente. Há neles, porém, um traço comum interessante: a presença do elemento teológico (elemento, aliás, enfatizado também por Petropoulos em seu artigo, como vimos). No texto sobre as Confissões, isso é naturalmente esperado, já que as especulações metafísicas sobre o tempo, a matéria e o movimento são feitas por um filósofo-teólogo, com base, também, no tratamento das sagradas escrituras. Nos casos da análise das obras de Spinoza, Descartes e Leibniz, segundo o antigo problema do uno e do múltiplo, vale notar como esses pensadores comumente agrupados na história da filosofia, por sua ênfase em uma abordagem matematizada do conhecimento, abarcam os temas teológicos em sua especulacão metafísica. Destaca-se, ainda, no artigo de Pugliese, o valor positivo do próprio paradoxo, pois mesmo que se busque clareza e precisão no discurso filosófico, o pensamento tem seus limites, e os paradoxos servem para aprendermos a conviver com eles. Colocado em termos míticos, se não podemos sair do labirinto (que nossa própria mente pode criar), que, pelo menos, qual Ariadne, aprendamos a dançar nele. No caso de Hegel, destacamos que, para compreendermos sua análise comparativa entre a arte grega e a egípcia, não devemos nos esquecer de que esta última é definida como uma expressão sensível do divino, ou, nas palavras de Cecchinato, na arte, mais precisamente na escultura, "si esprimono, in modo eminente, la congiunzione del divino 
e dell'umano nella forma humana". Como a autora mostra, o labirinto serve de metáfora para falar da arte egípcia, que é diferente da grega, e na qual a matéria é completamente penetrada pelo espírito.

$\mathrm{O}$ volume se encerra com três artigos que se inserem em problemas dos séculos XX e XXI de natureza bem diversa: política, lógica e estética. Motivados por questões contemporâneas, os autores analisam os termos-chave propostos, fazendo um contraponto entre sua compreensão na atualidade e na Antiguidade. Walter Menon, em "A vigilância como instrumento paradoxal da liberdade", fundando-se, principalmente, em Foucault, analisa os dispositivos de segurança e controle que, paradoxalmente, permitem que na democracia moderna (inspirada no modelo grego) a liberdade possa, de fato, ser mantida como valor e possa ser usufruída pelos cidadãos. Em seguida, temos dois textos também motivados por questões contemporâneas, analisados por um contraponto com a Antiguidade, mais precisamente com Aristóteles, mostrando tanto a permanência como as transformações de conceitos, principalmente o de contradição e paradoxo, nos campos da lógica e da estética. O texto de Abílio Rodrigues Filho, intitulado "Contradições: de Aristóteles à paraconsistência", talvez possa parecer deslocado em uma revista dedicada aos estudos antigos e medievais, pela ênfase na lógica clássica (que se desenvolveu a partir do século XIX, ligada à linguagem da matemática, e que não deve ser confundida com a chamada lógica aristotélica, por exemplo). No entanto, além do valor em si, ao apresentar pontos-chave da história da contradição - uma das consequências do paradoxo -, o artigo ajuda-nos a argumentar que a separação entre humanidades e ciências exatas, mesmo que necessária do ponto de vista pragmático na estruturação acadêmica das universidades atuais, não deve impedir que o estudo de conceitos-chave na evolução do pensamento filosófico, científico e religioso se dê por meio da interação cooperativa. E vale lembrar que uma das finalidades desses simpósios é a de reunir especialistas de diferentes campos para que seus trabalhos específicos se alinhem em uma visão de conjunto de problemas ou conceitos que estão na fronteira entre diversas disciplinas. Como se pode ver, a variedade de abordagens e temas encontrados nos artigos reflete esse espírito. Quanto ao último texto, de Dana Munteanu, "The Paradox of Literary Emotion: An Ancient Greek Perspective and Some Modern Implications", ele é instigante ao explorar, de uma perspectiva filosófica, obras de retores e filósofos que tratam, não da análise das respostas emocionais empáticas 
que temos diante de obras ficcionais (contrariamente às que temos em casos reais), envolvendo experiências vicárias de dor e sofrimento, mas do próprio fascínio com nossa capacidade de compaixão diante de obras dramáticas. Os exemplos de situações atuais de sofrimento humano devido à guerra, ao exílio ou às catástrofes trazidos pela autora vêm ressaltar essa diferença entre emoções sentidas em relação ao ficcional e ao real, e com eles a autora parece dar razão a Novalis, em sua afirmação de que a Antiguidade não vem a nós por ela mesma, nem é de fácil alcance, mas, bem ao contrário, temos de saber como evocá-la. ${ }^{6}$

Destarte, concluo esta introdução e exposição das motivações e opções temáticas que estimularam o convite aos simposiastas, pesquisadores da Antiguidade greco-romana e de sua recepção, voltando ao texto platônico, do qual foi retirada a epígrafe desta apresentação, que, por seu turno, também indica o ponto de partida filosófico na realização do simpósio e deste volume, mas que busca o diálogo com importantes áreas afins, como literatura e história. Como se sabe, no Eutidemo, o jogo de palavras dos chamados erísticos - jogo construído por Platão, não nos esqueçamos! - domina a cena. Nesse campo de batalha, no qual modos distintos de educação são defendidos pelos antagonistas, chegamos ao fim com a afirmação de Críton de que ele se encontra "sem saída" (દ่v ảjopía cỉì̀, 306d3) em relação à educação de seus filhos, em particular à do mais velho, que ele desejava encaminhar para a filosofia. A resposta de Sócrates (com a qual o diálogo é concluído) é recomendar a Críton que deixe de lado os outros e investigue por si mesmo o valor da filosofia. Para a realização do simpósio, pudemos e (obviamente) tivemos de fazer, em um primeiro momento, esse exercício de investigação de termos, conceitos e problemas, atividade solitária, pesquisando e redigindo. No entanto, não podemos ignorar o estímulo e o valor do encontro acadêmico, quando "enfrentamos o touro, pegando-o pelos chifres", entendendo que, nele, também, cooperativamente, dialogamos, compartilhando os primeiros resultados na compreensão dos quatro termos propostos para reflexão, bem como de alguns conceitos correlatos. Após atrelar e desatrelar fios, refazendo os passos, concluímos os textos que, publicados agora, tornamse objetos para outras leituras e investigações.

\footnotetext{
${ }^{6}$ Adapto, numa tradução livre, a epígrafe do estimulante opúsculo de Salvatore Settis, em sua edição inglesa, The Future of the Classical. Cambridge: Polite Press, 2006.
} 